\title{
METATHEATRICAL ASPECTS IN “THE AUTHOR” BY TIM CROUCH
}

\author{
Anna Savyna \\ Postgraduate Student, Zhytomyr Ivan Franko State University, Ukraine \\ e-mail: anka.sawina2011@gmail.com, orcid.org/0000-0001-9500-3623
}

\section{Summary}

Metamodern aesthetics and its key characteristics are usually viewed through the prism of a determined swing or whirling. Like a pendulum, it follows a certain trajectory: moving from modernistic seriousness, elitism, historical codes, mythological allusions to irony, carnivalization, mass culture and comes back, thus becoming a pérola barroca, which has two polar sides in its flexible core. Metamodernism claims for a greater depth due to its self-reflexiveness and selfawareness, which manifested in contemporary literary practice, drama in particular. The article aims to study the development of the meta-concept within the theatrical method and provide the systematic overview of the metatheatricality and metadramaticity based on the play "The Author" by Tim Crouch. As the result of the presented survey, it is found that the development of theatrical innovations is marked by changes in the author (playwright)-recipient relationship, the distance between stage and the audience, inclusion of the author's position through a reasoner and the alienation effect. "The Author" represents the implementation of the above-mentioned innovations through different levels of metatheatrical devices: the play within the play, selfreference, role-playing within the role, the ceremony within the play, and literary and real-life reference. The problem outlined in the article is not limited to the presented research and its prospects lie in the complex analysis of the "metatheatre" as a metamodern notion.

Keywords: metacharacter, metadramaticity, metamodernism, metatheatre, mise en abyme.

DOI: https://doi.org/10.23856/4909

\section{Introduction}

Contemporary dramatic studies are undoubtedly connected with several main trends and movements. Playwrights either return to the Greek (or Aristotelian) form of drama by following its rules or try to move much further, taking non-Aristotelian drama as a start-point. Nevertheless, it is not fair to completely deny the crucial impact of the Poetics on contemporary drama tendencies and dramatic criticism, as postmodernism itself welcomes to keep the balance between antique aesthetic traditions and modern drifts. Moreover, some of the literary critics suggest using in such a context the concept of metamodernism to highlight the slight changes in the artistic paradigm that became popular in the $1980^{-\mathrm{s}}$.

The term "metamodernism" was introduced in 1975 by Mas'ud Zavarzadeh, who interpreted the notion as a vague bunch of aesthetic and literary practices that emerged since the mid-1950-s. Further Robin van den Akker and Timotheus Vermeulen, in the essay Notes on Metamodernism (2010), expand the interpretation by stating that the postmodern era has come to an end. Postmodernism is replaced by metamodernism, which, by all means, introduces the future that is futureless and displaces the boundaries of our place with those of a surreal place that is placeless. Thus, the "destiny" of metamodern man is to chase a floating horizon (Vermeulen \& Van den Akker, 2010). 


\section{The meta-concept and theatrical practices}

These tendencies one may trace also in theatre, where the meta-concept becomes increasingly popular. The spectrum of variation range that alters between the serious and the ironic, modernism and postmodernism, objective images and models of the world, as well as an appeal to classical models, actualizes the processes that take place in contemporary literature, drama in particular.

Metaization as a peculiar feature, on the one hand, comes from Greek prefix "meta-", which etymologically stands for beyond, above, describing the upper levels of something, but on the other hand, is connected with Plato's metaxy. Metaxy signifies the binarism of existence, the "in-between" situation mode (Vermeulen \& Van den Akker, 2010). However, it is not an exaggeration to say that contemporary dramatic and theatrical practices are now "in the middle" or "in-between" and "beyond". The development of theatrical innovations, including metatheatricality and metadramaticity, refers to Bertolt Brecht's theory of epic theatre. Changing the relationship and the distance between scene and audience, the inclusion of the author's position through a reasoner, the alienation effect (V-Effekt) serve to destroy the fourth wall. In relation to these peculiarities, theatrical praxis responds to what stands behind the prefix "meta-".

Nevertheless, the contrast between mimetic and self-referential drama is a problem of theatrical levels rather than an absolute delimitation of two inconsistent views (Pérez-Simón, 2011). In this regard William Egginton emphasizes, "there can be no theater that is not already a metatheater, in that in the instant a distinction is recognized between a real space and another, imaginary one that mirrors it, that very distinction becomes an element to be incorporated as another distinction in the imaginary space's work of mimesis" (Egginton, 2003: 74).

Initially, the idea of metaplay and metatheatre appears in the eponymous collection of essays, written by Lionel Abel in 1963. Abel views metatheatre as a philosophical form of drama, self-conscious by its nature. He draws attention to the characters from the works of Shakespeare, Cervantes and Calderón, stating that they are conscious of the part they play in constructing the drama (Abel, 2003: 167). According to Abel, metatheatrical plays have a common feature - they present life as already theatricalized. The characters that appear on the stage are pragmatically "dramatic". From this point of view, it is possible to trace the connection between metatheatricality/metadramaticity and intertextuality, since the characters become dramatized originally by myths, legends, past literary texts or simply by themselves (Abel, 2003: 134-135).

Yet, metatheatre cannot be limited only to these explanations as it is not just about the self-consciousness of the characters or the self-reflexiveness of the very theatre. Metatheatre goes, as we may understand by definition, far beyond. To understand better the full depth of the idea of metatheatricality, it is essential to pay attention to contemporary plays, which embody the notion on the stage, in front of the spectators.

\section{3. "The Author" by Tim Crouch}

A prime example of such an embodiment might be The Author (2009) by Tim Crouch, famous for such plays as My Arm (2002), An Oak Tree (2005), ENGLAND (2007) among others. The playwright's creative method is marked by experimentation: the rejection of theatrical conventions, unusual dramatic forms, spectatorial engagement etc. Interviewed in 2007 by Mark Fisher he said:

Theatre in its purest form is a conceptual artform. It doesn't need sets, costumes and props, but exists inside an audience's head (Fisher, 2007). 
The theatrical tinsel is of less importance to Tim Crouch: on the contrary, he focuses on the simple things, such as the drama itself, the characters and the spectators. However, even at these levels the metatheatrical orientation of The Author is evident.

Richard Hornby, a distinguished theatre critic and director, in his work Drama, Metadrama and Perception (1986) designates five types or devices of metatheatre: the play within the play, self-reference, the ceremony within the play, role-playing within the role and literary and real-life reference (Hornby, 1986). These key characteristics might be extrapolated to The Author.

The play reflects the notion of mise en abyme. It is a complex work, constructed as "the play within the play" which has different facets of meaning. The Author presents the process of creating the play and its further reception by the audience. This is the semantic frame of the play, although its "heart", the narrative on which all the thematic layers are strung, is a contemporary story about child abuse. The frame story is written by one of the characters Tim (the author) for the Royal Court Theatre. To create such a play Tim explores the topic of cruelty and violence provided in the form of an interview with someone, who is a subject of such an experience. He also reviews some extreme sexual and violent videos and images, which he shows to the cast members during the rehearsals. Tim explains the purpose of the play, considered by many critics as violent:

My intention was to deliver a shock - to create a - an amateur war zone on the stagelike a physical blow. A simulation of a physical blow. To represent what was happening in the real world. To show what was happening. Not in my life, of course, thank god, I'm incredibly lucky. But what I perceived. What we all perceived. The ethics of the images we saw. To push that to the extreme. Art operates in the extreme (Royal Exchange Theatre, 2014: 33-34).

The quote from the play is connected with the drama of "New Brutalism" or so-called "New European Drama", popular during 1990-2010. Although this trend, according to different theatrical critics, has declined in popularity, several artists still cling to the phenomenon. Tim Crouch's plays are typically coordinated by the In-Yer-Face theatre paradigm. He supports Aleks Sierz's idea about employing shock tactics and questioning moral norms that In-Yer-Face theatre is famous for (Sierz, 2001: 4). Tim (the character) develops the mentioned above idea further by stating the following:

The violence is there as an underscoring to the central relationship. The father and his daughter. The abuser and the abused. A way of getting the characters closer to each other, just a dramaturgical device, really. The violence is not the most important thing, which some of the reviewers seemed to suggest. But it can't be avoided. I mean look around us. Society is defined by its edges, isn't it? Not by its centre. I think I'd become more and more absorbed by images from the edges. I think we all had! Just through everyday exposure, really. And a hunger to see what was going on. What had become possible in the world we lived in. What had become recently possible. Or possible again. Riven flesh, severed limbs, decapitated heads (Royal Exchange Theatre, 2014: 31-32).

It is the very essence of the theatre - to expose what happens in the real world. In this case, the drama follows a mimetic tradition, and the action does not separate the reader/ the spectator from cruelty or violence but plunges them directly into it. At the same time, the formality of what is shown on the stage (even there is no real stage) exists. This convention is provided by the author's remark, which opens the play. It says that The Author is set at the Royal Court Theatre even when it is performed elsewhere, and indicates the unity of the place, and brings a fictional connotation to an allegedly realistic work (Royal Exchange Theatre, 2014: 18). Thus, theatre is a safe intermediate for delivering and experiencing the shock. Theatre becomes a metamedium that associates reality and illusion. 
"The play within the play" model is also highlighted through Chris, one of the characters, a fictional and exaggerated embodiment of a connoisseur. Being a true "friend of the theatre", he does not miss a performance, always books tickets when the season is announced and happy to share his emotions and impressions with others. For example, he shares with the audience several facts from the violent play he has attended:

The title of the play referred to the girl, I suppose. It was her face on the poster, in the brochure - looking dreadful! Although it was more about the father and the war or whatever. I knew her because I'd seen her before - in that film, where she was the girl. I didn 't know him, though, the father. I thought he was marvellous. And of course I knew of the writer - who was also directing (Royal Exchange Theatre, 2014: 34-35).

Chris is a metacharacter because he is located inside the "frame-play", where he tells about his experience as a spectator of another play. Moreover, he represents self-reference another metatheatrical device. Chris is the first character to meet the audience and the last to make the farewells. He breaks the fourth wall by reading a review of The Author to the spectators at the beginning of the play, providing the synopsis of what happens on the "stage".

Initiating a dialogue with the audience, Chris reflects on the actors and characters, accepting the fact that he is fictional himself:

I think we're better looking than actors, don't you? Do you, ___ ? Look at us! Look! We're gorgeous! Maybe not better looking... But more realistic! <.. > But I often think - I thinkI think that sometimes the most fantastical - the most made up thing in the theatre is us! $<\ldots>$ I saw a play last year. And I remember thinking, 'that writer has imagined me'. I've been imagined! Poorly imagined! The audience has been badly written! We're all going to pretend ourselves! (Royal Exchange Theatre, 2014: 21).

Though, his artificiality makes him appear more realistic to the spectators. Besides, by delivering the afore-mentioned lines, he refers, as a reader/ the spectator assumes, to the play itself, validating its meta-nature. Chris contemplates the nature of character/ actor relation, but there is Vic - another character, who intensifies it. He draws attention to the actor-audience interaction. This relationship is constructed through the characters' speech - monologues and dialogues, thus, before delivering a speech, Vic insists that it is important to get to know one's audience. The actor's task is to give the audience a character and a relationship, but the effect is achieved only when the audience is active through feedback. Then drama becomes provoking, rousing, stirring (Royal Exchange Theatre, 2014: 25).

An appeal to the active participation of a spectator (primarily intellectual) furthermore alludes to Bertolt Brecht. Therefore the audience interprets a truth for the most part independently, following the author's ideas. The author as a figure from the play is also important for providing self-reference. The author-reference originates from the very title of the play. Tim (character) represents several social roles - he is the author, director, actor, member of the audience, colleague, friend and husband. Tim identifies himself in the play as Here I am, a civilized man, a theatregoer! A writer (Royal Exchange Theatre, 2014: 35), but not all of the above-mentioned roles are real. Tim Crouch, like Bertolt Brecht, initially creates the illusion of a real-life situation and then destroys it, using theatrical self-references, which provide alienation effect, throughout the play. Evidently, he abandons the concept of catharsis, because as soon as the spectator begins to empathize with the characters, Crouch reminds that the stage action is not more than the author's fiction. It is coherently related to the next aspect of metatheatricality - role playing within the role.

According to the opening remark the names of the characters should correlate with the real names of the actors, except for the author, whose character's name should invariably remain Tim Crouch. The actors apparently play themselves or create such an illusion. However, 
role playing within the role is potentially diverse, because in a similar way, it deals with the play within the play. In this regard, Esther reflects on her experience of playing a part of the abused child in Tim's play, she says:

We had to go out into the city and find someone who connected with the themes of the play. We had to study them and interview them and then bring back what we'd observed. It was brilliant because we'd done loads of that kind of staff at Drama Centre. I went to a shelter for women who had suffered domestic violence. I was really lucky. I met a woman who had been raped as a teenager by her father. That's just like my character, I said! (Royal Exchange Theatre, 2014: 40).

Then the interview is transferred into the theatre and played out in front of the spectator/ the reader:

ESTHER Her name was Karen. She was like this. Can you see that? Her tension here. Her eyes like this. A filthy track suit.

TIM Hello Karen.

ESTHER Yeah.

TIM Thanks for agreeing to talk with us.

ESTHER I'm not -

TIM It's okay. We're just really pleased that you could be here with us. Aren't we? We just wanted to get to know you, really, to hear a little bit about you. We're really interested in you, aren't we? Aren't we?

VIC Yeah!

ESTHER Yeah?

TIM Do you want to talk about what happened to you? About why you're there?

ESTHER What?

TIM In this place.

ESTHER In the shel'er?

TIM In the shelter or in the theatre. It's up to you. Wherever you want to be.

ESTHER I don't wanna be 'ere. <...>

TIM Do you want to talk about your dad?

ESTHER No.

TIM We understand. It won't go any further than this. Do you want to tell us about what he did? What he made you do?

ESTHER No. Stuff. $<\ldots>$

TIM What kind of staff? <... $>$

ESTHER Films and pictures and stuff. $<\ldots>$ He put things - filmed me with his mates. Putting things inside me. What 'you fucking think he did? Read me fucking story books?

TIM I'm so sorry.

ESTHER No you're not. You're not fucking sorry. None of you are fucking sorry.

VIC How old were you when it started, Karen? <.. >

ESTHER Twelve. <...>

TIM How did that make you feel, your dad doing these things? Karen?

ESTHER Can we stop, Tim? (Royal Exchange Theatre, 2014: 40-43).

In this episode Esther plays Karen, who is being interviewed to understand better the part as Eshna. Although it is not an impersonation, but rather a reference point. Here Tim Crouch introduces pseudoverbatim technique. On the one hand, there is an interview that seems to be a documentary, but on the other hand, it is made-up. The line between reality and fiction is slim. The spectator/ the reader is not fully aware of whether the story that is being told is real. 
The audience may constantly ask questions, such as: Can we trust the author? Do we need to analyze everything that happens in order to understand where the truth is? This puzzle is a consequence of both literary and real-life references. For example, there is an allusion to Shakespeare's Hamlet, where the model of the play within the play is realized, though it has another purpose than in The Author. Moreover, the play mentions one more important real-life reference - when in a protest the theatres worldwide unanimously took a strong anti-military standpoint. The movement is famous under the THAW abbreviation. This allusion probably becomes the background of the whole play as its structural component.

\section{Conclusions}

Despite everything that has been already mentioned, perhaps the main role in the creation of the metatheatre is assigned to the audience (Cahill, 2015). The Author is a metaphor that stands for the reception of the literary discourse. When the author dies in the play, the active and mindful spectator must be born. Eventually, the writing leaves its creator, and the end of the play depends on the audience.

\section{References}

1. Abel, L. (2003) Tragedy and metatheatre: Essays on dramatic form (M. Puchner, Ed.). New York and London: Holmes \& Meier.

2. Cahill, A. (2015). The Theatrical Double Reflexivity Complex: How the Spectator Creates Metatheatre. Studia Universitatis Babes-Bolyai - Dramatica, (2), 173-188. Retrived June, 02, 2021, from https://core.ac.uk/download/pdf/74392867.pdf.

3. Egginton, W. (2003). How the world became a stage: Presence, theatricality, and the question of modernity. Albany: State University of New York Press.

4. Fisher, M. (2007) England - Art of the matter. Retrieved June 02, 2021, from https:/ledinburghfestival.list.co.uk/article/2505-england/.

5. Hornby, R. (1986). Drama, metadrama and perception. Lewisburg, Pennsylvania: Bucknell University Press.

6. Pérez-Simón, A. (2011). The concept of Metatheatre: A functional approach. TRANS-, (11). doi:10.4000/trans.443.

7. Royal Exchange Theatre (2014). The Author by Tim Crouch. Retrived June, 02, 2021, from https://issuu.com/royalexchangetheatre/docs/the_author.

8. Sierz, A. (2001). In-yer-face theatre: British drama Today. London: Faber and Faber.

9. Vermeulen, T., \& Van den Akker, R. (2010). Notes on metamodernism. Journal of Aesthetics \&amp; Culture, 2(1). doi:10.3402/jac.v2i0.5677. 